Giangiacomo Minak

Associate Professor Department of Industrial Engineering Alma Mater Studiorum University of Bologna Viale Risorgimento 2, 40136 Bologna

\section{Cristiano Fragassa}

Assistant Professor Department of Industrial Engineering Alma Mater Studiorum University of Bologna Viale Risorgimento 2, 40136 Bologna

Ana Pavlovic

Adjunct Professor Department of Industrial Engineering Alma Mater Studiorum University of Bologna Viale Risorgimento 2, 40136 Bologna
Determination of Stress Distribution in Women's Shoes During High-Heeled Gait

This work is aimed at investigating loads, strains and stresses emerging in a pair of women's fashion shoes during high-heeled walking with the general objective to improve the footwear safety. In particular, the resistance of an 11-centimetre heel in women's shoes was evaluated by experiments under the most common conditions of use (e.g. walking, standing, sitting on a car, getting up from a chair, going downstairs and upstairs, jumping). The heel was substituted by a strain gage instrumented aluminium hollow cylinder with the capability of measuring the deformations in several critical points. These measures permitted to implement a complete time depending stress-strain analysis. Deformations were also related to forces and moments acting on shoes, experimentally deriving these actions for each condition of use. A comparison with stresses generated during standard tests was also performed.

Keywords: Footwear, women's shoes, safe walk, strain gages, ABS, PMMA

\section{INTRODUCTION}

Shoes are among the most important consumer goods and a largely common necessity. Moreover, the quality of footwear can play a relevant role in the daily quality of life of each one. Therefore, shoes are always designed to meet a mix of complex requirements, involving functional, ergonomic, hygienic, aesthetic and physiological aspects [1].

In particular, between many others, functionality and ergonomics together seem to represent the most relevant product's properties, reflecting the footwear's ability to meet the needs and desires of each person in terms of comfort and usability during the walk [2].

These requirements impact on several fundamental parameters of design such as, for instance, size and height of the shoe, height and tough of the heel, and many others. But, also additional technical aspects, less obvious at first sight, can emerge in defining the footwear's general usability, as weight, stiffness, friction, etc..

At the same time, additional aspects, related to the style, aesthetics and fashion, more difficult to be transformed in rigid design parameters, reflect the ability of shoes to catch the desires of customers.

Key indicators of a potential market success, based on aesthetics, are the shoes' compliance with artistic tendencies, information, expression, rationality forms, composition integrity, stability in presentation [3].

Unfortunately, ergonomics and aesthetics are far away from proceeding in parallel toward an optimal design strategy. On the contrary it is quite common that

Received: August 2016, Accepted: October 2016

Correspondence to: Ph.D. Cristiano Fragassa

Department of Industrial Engineering, University of

Bologna, Bologna, Italy

E-mail: cristiano.fragassa@unibo.it

doi:10.5937/fmet1703315M

(c) Faculty of Mechanical Engineering, Belgrade. All rights reserved solutions, appreciated for their beauty, are demonstrated quite pour in terms of functionality [2].

It is, typically, the case of heeled shoes, where the risk related to the use of high heels improves increasing their height, together with their fashion [4].

A design compromise between different wants of safety and style has to be searched and a large number of studies analysed these aspects.

In [4], for instance, the impact of high heeled shoes on kinetic changes and perceived discomfort was investigated. This information was used as basis for the design of shoes aiming at minimizing the adverse effects on the human musculoskeletal system. In [5] the heel strike was generally characterized with the aim at investigating the effect of this transient phenomenon on the alteration in the activation timing of muscles.

On the market, quality is assumed, in general, as the totality of characteristics of footwear that determines the ability for shoes to satisfy stated and implied needs. All these factors (as functionality, style...) contribute, with a different relevance or importance, to the quality of final products and can be used to improve them.

It is noteworthy that, nowadays, besides the specific quality requirement used for improving the shoes, the overall quality of the footwear represents one of the most important factors in determining the level of competitiveness of enterprises.

Between all the other quality specifications, the reliability represents a complex property that combines the dependability, the durability, the dimensional stability and additional characteristics [6,7]. Durability, in particular, usually depends on the material properties, the intensity of socks, soil-climatic conditions, the bond strength of parts, the existence of hidden defects. This durability can be evaluated by experience or by experiments, often regulated by standards [8-11]. A lack 
in durability can result in drastic effects since involves aspects of personal safety.

Statistics collected in the US showed that more than 20.000 women per year use to visit hospital or podiatrists due to falls or sprained ankles, and that high heels are one of the biggest factors leading to foot problems in women [12]. Up to a third suffers permanent problems as a result of prolonged wear of unappropriated shoes leading to foot in a downward position. In this case, there is a significant increase in the pressure on the bottom (plantar) of the forefoot.

This pressure increases as the height of the shoe heel increases [13]. In [14] a quantification of the path of center of pressure during the stance phase, the balance and pattern of progression was performed. For instance, wearing a 8-centimetre heel raises the pressure on the bottom of the forefoot by $76 \%$. This increased pressure can lead to pain or foot deformities such as hammer toes, bunions $[13,14]$.

A safe heel becomes a fundamental aspect of shoe design. But, safety in walk is not only a problem of hells' dimension and height: also the specific materials used for their realisation, have a fundamental role.

Heels should resist repeated impact loads, to possess high levels of specific impact strength, compression strength and bending strength, hardness, low density and low shrinkage. Since their criticality, first heels-stilettos were manufactured from a metal rod. Until recently, medium to high heels for women's shoes were made of wood. Currently, plastic is largely preferred. Plastic heels are made by thermoplastic polymers: polyamides (nylon secondary resin), polyethylene, polystyrene, polypropylene, etc.

In the last years, in fact, designers have tried to combine style and product reliability introducing in a mature market in materials and processes with the aim at offering a competitive advantage to their products. Next improvements will continue to follow this scope and will probably take in count of the use of reinforcements in polymers, as natural fibers [15] or advanced nanofibers [16], but also uncommon treatments [17] or unconventional processes [18].

This continuous evolution in technical advances toward new and highly performing solutions also requires an accurate familiarity with the biomechanics of walking, the material properties and the stress-strain levels emerged in shoes during walking.

In [19], the six-components of forces were measured on the feet during locomotion by transducers. A shoeshaped structure, having a hinge in its middle place, was worn on the foot of a tester. A potentiometer registered flexion or extension of angles during gait motion. In this analysis the support phase transition of the feet for a human body weight during the normal gait cycle was considered. This assumption is inapplicability in the case of walking with high heel shoes where the legs' are forced in unnatural positions and movements [20].

A large number of experimental researches are related to the investigation of the different aspects of walking by high heeled shoes. The base for comparison is in [21] where a range of normal in-shoe pressure values was established using sport shoes.

This analysis helped to identify normal subjects or abnormalities in motion. Adding, the repeatability and consistency of measures for one of the most commonly used systems for in-shoe pressure measurement. on which clinical judgements are verified.

Then, in [22] a heel-mounted accelerometer permitted to measure the floor slipperiness giving useful information of safety to the shoes' designers. At the same time, in [23] several methods were proposed for checking the validity of procedures used for measuring this slip resistance.

\section{METHOD AND MATERIALS}

\subsection{General scope and phases}

The aim of this work was to test a pair of high heeled fashion shoes with the general objectives to:

- demonstrate heel reliability by experiments;

- improve the heel and sole mechanical performances;

- confirm the validity of standard procedures used in heel testing

This result was implemented passing through several steps:

1. preliminary analysis of biomechanics of movements in the case of high heeled shoes

2. selection of the most representative situations and movements

3. development of suitable experimental equipment and testing procedures

4. calibration of equipment and instruments

5. detection of heel's deformation by strain gauges and stress evaluation

6. determination of the relationship between common movements and stress on heel

\subsection{General scope and phases}

According to the manufacturing information, soles and heels shoes used inside this experiment were, respectively, realized by 2 different thermoplastic materials: acrylonitrile butadiene styrene (ABS) and polymethyl methacrylate (PMMA). A comparison of mechanical properties is reported in Tab. 1.

Table 1. Comparison of mechanical properties between ABS and PMMA (at $23^{\circ} \mathrm{C}$ )

\begin{tabular}{|l|c|c|c|}
\hline Property & Units & ABS & PMMA \\
\hline Density & $\mathrm{g} / \mathrm{cm}^{3}$ & 1.024 & 1.218 \\
\hline Tensile Strength & $\mathrm{MPa}$ & 44.8 & 68.9 \\
\hline Flexural Strength & $\mathrm{MPa}$ & 75.8 & 117.2 \\
\hline $\begin{array}{l}\text { Compressive Strength } \\
(10 \% \text { Deflection) }\end{array}$ & $\mathrm{MPa}$ & 46.5 & \\
\hline Elongation at Break & $\%$ & 20 & 5 \\
\hline Tensile Modulus of Elasticity & $\mathrm{MPa}$ & 2200 & \\
\hline Flexural Modulus of Elasticity & $\mathrm{MPa}$ & 2275 & 2758 \\
\hline Hardness (Rockwell \& Brinell) & Various & $\mathrm{R} 105$ & $\mathrm{M} 93$ \\
\hline
\end{tabular}

ABS is a common thermoplastic used to make light, rigid, moulded products. Made by polymerizing styrene and acrylonitrile, the advantage of ABS is that this material combines the strength and rigidity of the acrylonitrile and styrene polymers with the toughness of the polybutadiene rubber. The most amazing 
mechanical properties of ABS are resistance and toughness. A variety of modifications can be made to improve impact resistance, toughness, and heat resistance. The impact resistance can be amplified by increasing the proportions of polybutadiene in relation to styrene and acrylonitrile although this causes changes in other properties. Impact resistance does not fall off rapidly at lower temperatures. Stability under load is excellent with limited loads.

PMMA is a thermoplastic and transparent plastic, sold by the different tradenames. It is commonly known as Plexiglas or simply acrylic. The material is often used as an alternative to glass. PMMA is 2 times less dense: its density can range from $1150-1190 \mathrm{~kg} / \mathrm{m} 3$ with a higher impact strength; PMMA does not shatter but instead breaks into large dull pieces. PMMA is softer and more easily scratched than glass.

\subsection{Equipment}

In term of instruments, the heel was replaced by a simulacrum of calibrated dimensions in which the loaddeformation relation was preliminary determined by theoretical considerations [23]. In Fig.1, the high heeled shoe used for testing is shown, together with details of heel, soil and of the instrumented simulacrum.

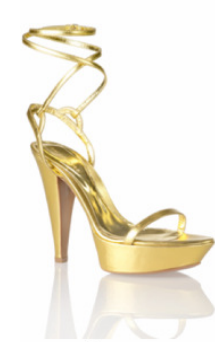

a)

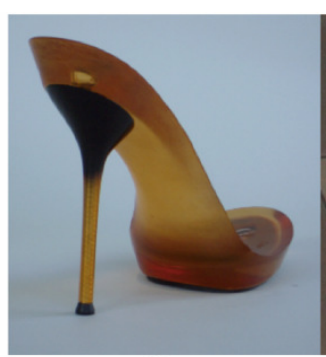

b)

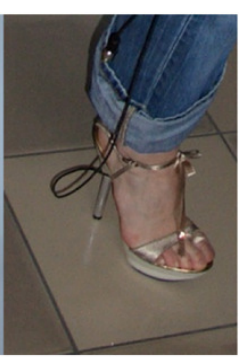

c)
Figure 1: High heeled shoe under testing: a) the shoe; b) details of heel and soil; c) the instrumented simulacrum.

This simulacrum was instrumented using 13 strain gauges, adapted to acquire axial deformation and bending in two planes. Load cells were designed to be able to acquire all possible stresses on a heel (normal, bending, torsion). In particular, as shown in Fig. 2, it was used:

- one Quarter-Bridge (QB) strain gage circuit for detecting the normal force $(\mathrm{F})$

- four Half-Bridge (HB) strain gage circuits to find the flexural moments in two different sections and two orthogonal directions

- $\quad$ one Full-Bridge (FB) circuit with strain gages at $45^{\circ}$ for detecting the torque $(\mathrm{T})$.

Similarly, strain gauges were also applied to the sole in order to determine the deformation on the whole shoe.

The calibration of load cells was realized in laboratory applying dead weights. In particular, a compression, two flexural loads on two orthogonal planes and torsional loads were separately applied with the aim at providing load-deformation curves in controlled conditions (Fig. 3).

In the case of normal force, the compressive force was obtained directly applying an established weight on the load cell (Fig. 3a). A lateral support and steel balls under the base permitted to eliminate undesired moments. Indeed, a cantilevered beam with an applied weight was used for calibrating the load cells for measures of flexural moments (Fig. 3b). The beam was turned until the measure was maximum. In the torque, the cell was clamped on one side, supported and loaded on the other side (Fig. 3c).

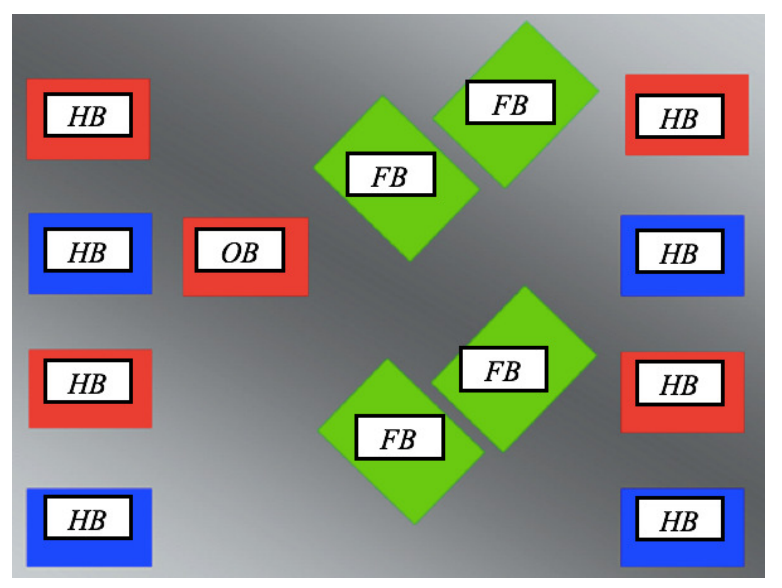

Figure 2: Load cell design with one Quarter-Bridge (QB), two Half-Bridge (HB) and one Full-Bridge (FB) strain gage circuits

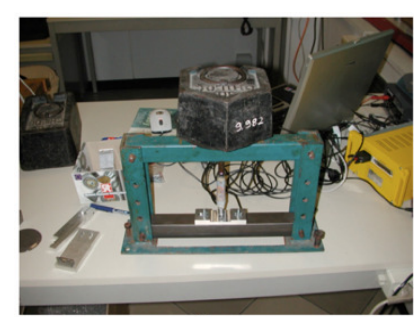

a)

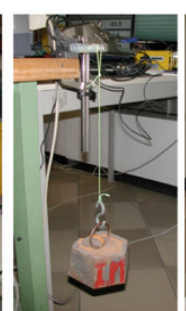

b)

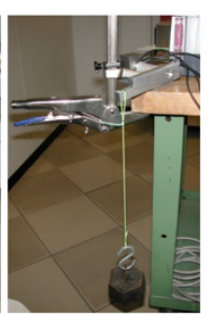

c)
Figure 3: Calibration of strain gages used for detecting a) normal force, b) moments; c) torque.

Data were acquired by Leane multichannel portable system shown in Fig.4, transported by the person wearing the shoe, allowing to acquire data in service conditions.

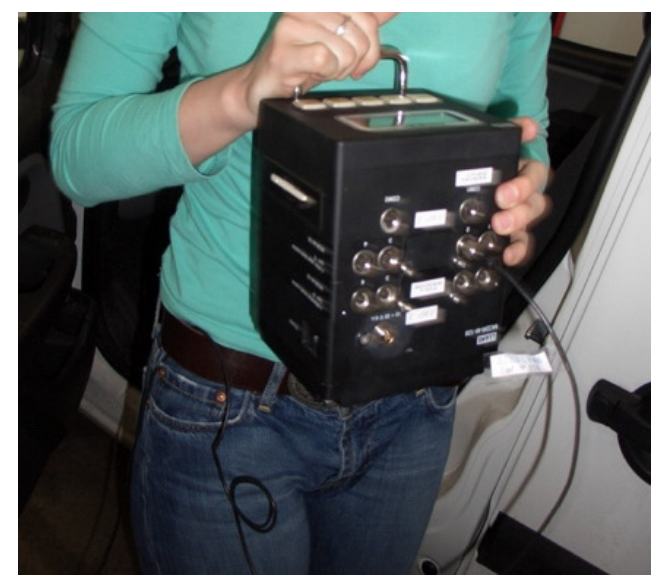

Figure 4: Portable testing device.

\section{RESULTS AND DISCUSSION}

\subsection{Tests and measures}

A women's shoe, 11-centimeter high heel, 36 European size, worn by a young woman of about $60 \mathrm{~kg}$ in weight 
without foot problems or any other mobility limitation was used for testing.

Tests were carried out considering several common conditions (Fig. 5) of use for fashion shoes as:

- $\quad$ lift and sit (on chair)

- walking (in a slow gait)

- going downstairs and upstairs

- $\quad$ entry and exit (in a car)

- jumping (as in dancing)

- $\quad$ random loads (sitting, crossing legs, picking coins)
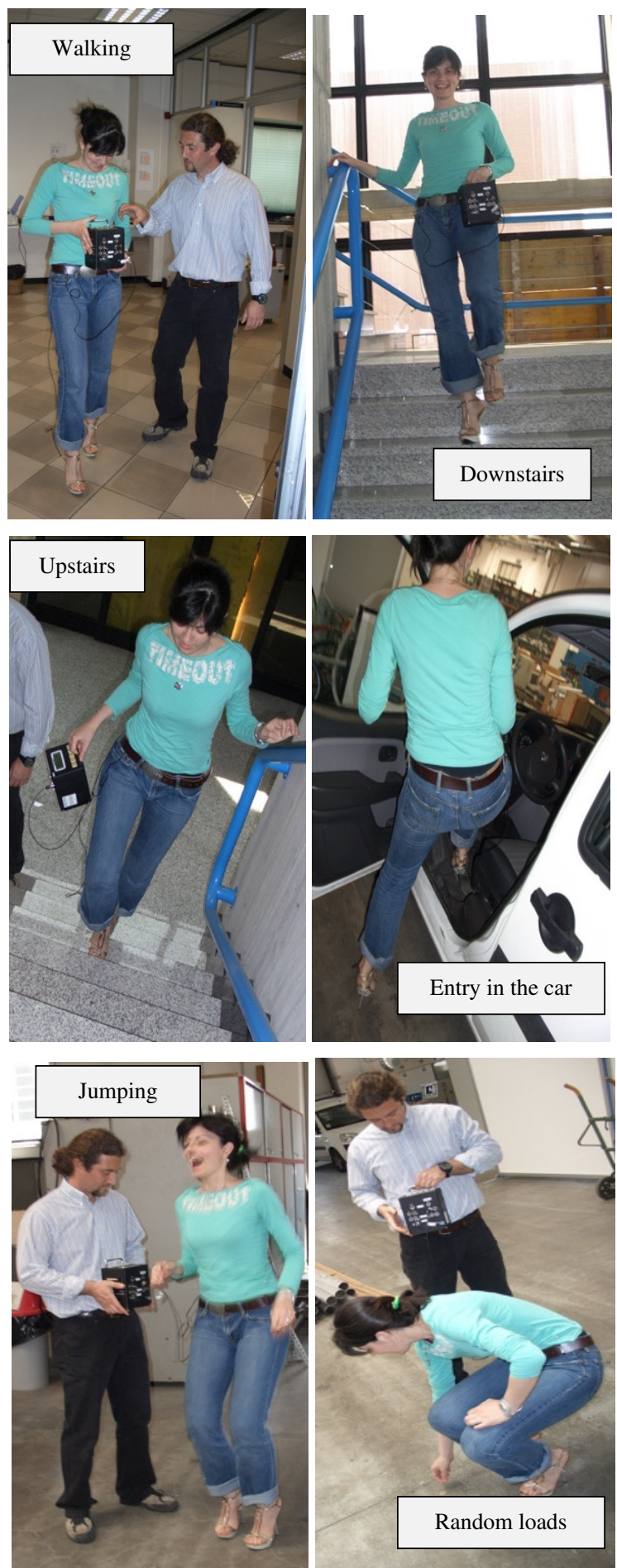

Figure 5: Testing the shoes in different conditions.

Once mounted the instrumented heel on the shoe, measures were provided in terms of time-depending deformations [24,25], recorded by the strain gages during several situations of utilize and related to the presence of compression, bending moments and torques (Fig. 6).
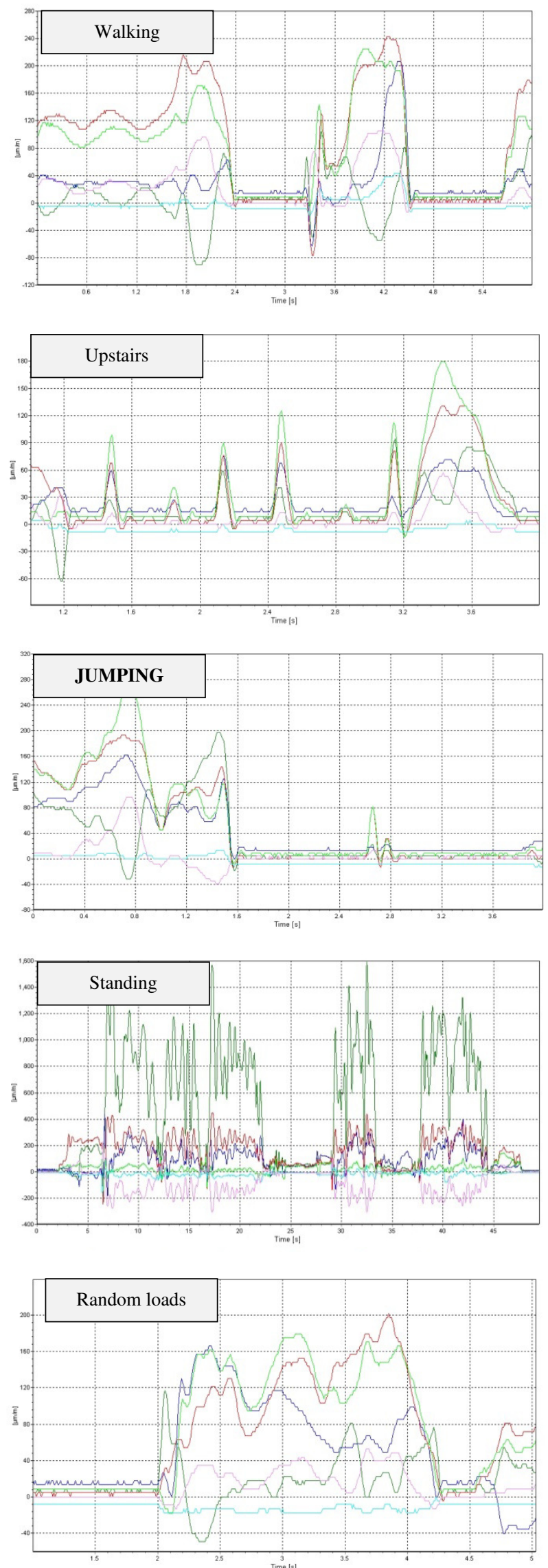

Figure 6: Time depending deformations recorded by strain gages in different operative conditions. 


\subsection{Stresses, Forces and Moments}

Considering the material properties, time-depending stress curves in the different operative situations (as walking, jumping, going upstairs or downstairs etc.) were obtained, as reported in Fig. 7.
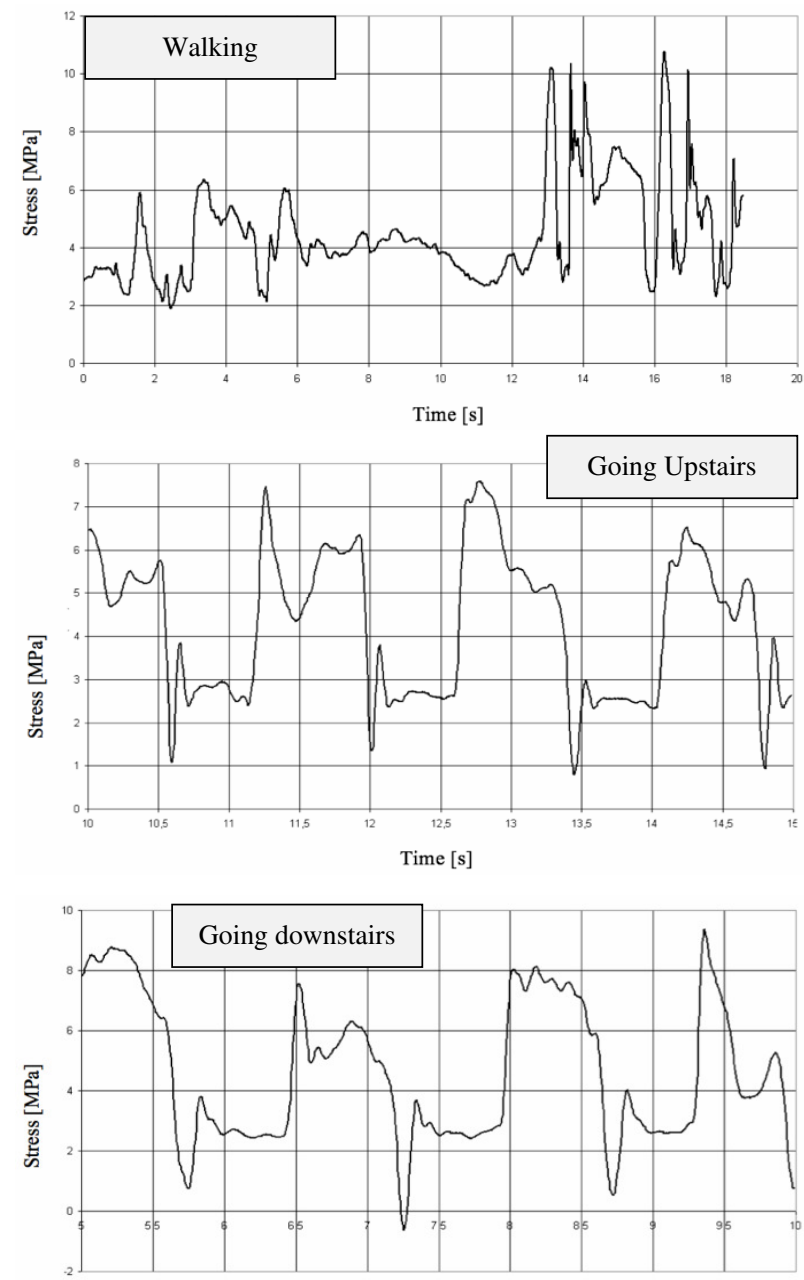

Time [s]

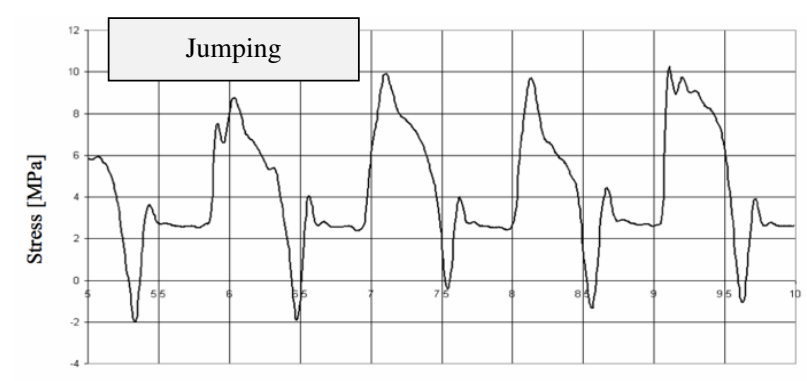

Time [s]

Figure 7: Time-depending stress diagrams during.

From these measures it was possible to determine a matrix that relates the experimental deformation with forces and moments. Using its inverse was therefore possible to derive these actions (force and moments) from the measured deformations (Fig. 8).

Graphs show the evolution of the normal force, sagittal moments (i.e. in the forward direction behind) and transverse moments (i.e., left-right direction) in various conditions.

Firstly, it is possible to highlight that the entity of the deformation is very low $(200 \mu)$ for most of the situations envisaged. There are exceptions represented, in practice, by the cases in which the heel is incorrectly used: not for walking or climbing a step, that are actions that require a good orthogonality, but rather in situations such as the crossing legs when sitting. In this and similar situations, a lost in the orthogonality of forces respect to the constrains can induce unexpected bending moments.

Also in the case of standing (e.g. while waiting), loads on heels can be largely increased by the body position. Usually, since a moderate but continuous waving of the centre of mass, requested by better balance on uncomfortable heels, legs do not work in the same way. In particular, the vertical load is supported for the most part on one leg and occasionally transferred on the other leg, partially inclined. This situation can redouble the force on the heel.

These cases of dis-alignment are characterized by high flexural deformations (up to $1400 \mu$ ) measured by the half-bridge in the sagittal direction at the closest point to the sole. A substantial signal was also noticed in the transverse direction.

A further consideration is related to the fact that the twist and the normal stress have an effect not even remotely comparable to the bending and, therefore, for future measures the load cell configuration can be limited to four strain gages in Quarter-Bridge.
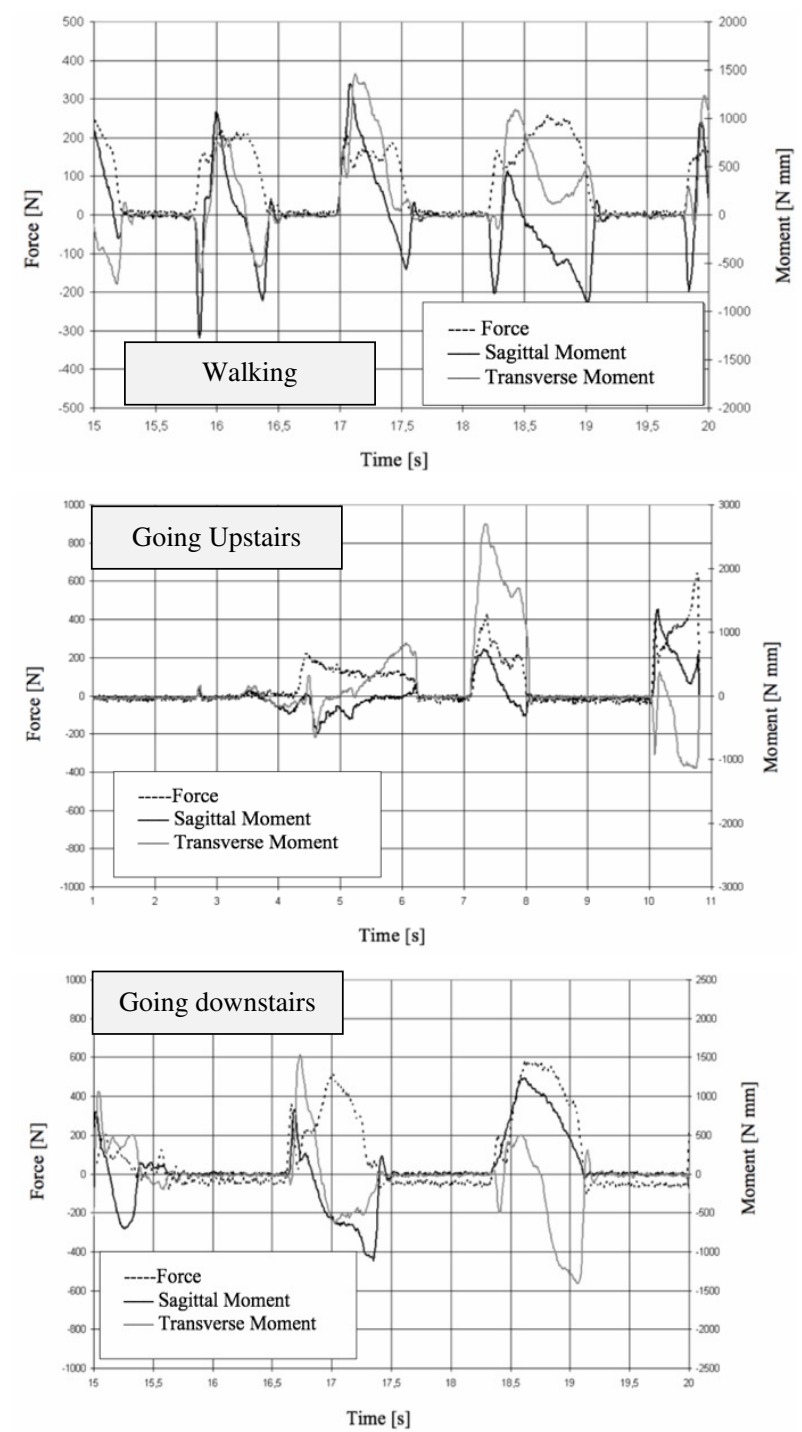

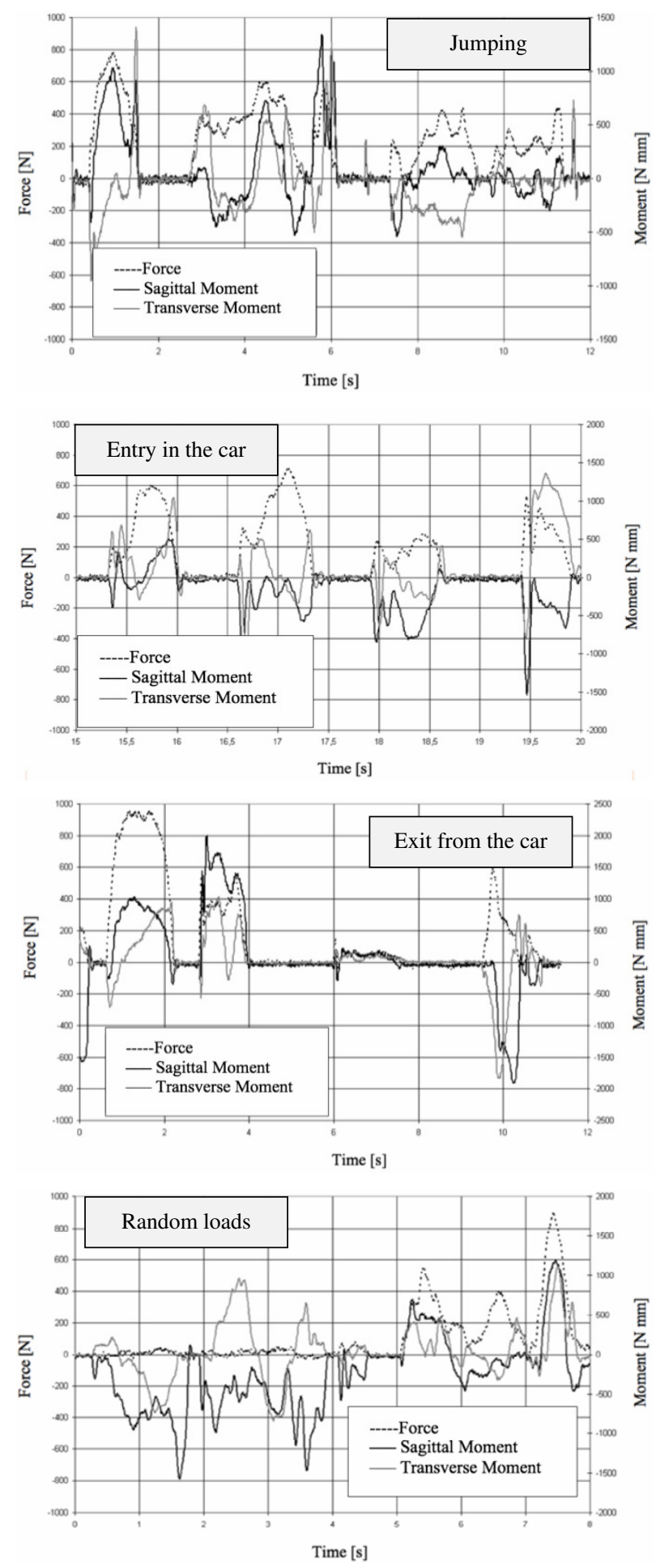

Figure 8: Time-depending force and moments in different operative conditions.

The normal load remains quite low in all cases with mild occasional increments: entering or exit from car and jumping represent the most critical cases for normal loads. However, despite the dynamic effects, the maximal value of these loads is limited to twice the woman's weight. This evidence permits to neglect the action of normal loads during investigations [26].

The maximum bending loads are approximately equivalent in all test conditions and vary between 1500 and $3000 \mathrm{~N} \mathrm{~mm}$. The transverse moment is of the same order of magnitude of the sagittal and sometimes higher (e.g. in climbing in the car). These moments are often of the same sign and sometimes of opposite sign, changing the stress on the heel in an unpredictable manner. In fact, while the presence of the sagittal moment is inherent to the movement, the transverse moment is to be considered as a disturbance caused by a not perfect control of the heel by the user. However, for a utilisation by non-professional wearers this aspect is to be taken into account.

There is reason to believe that the loads produced by having standardized tests are much higher (and still depend on the rigidity of the experimental set-up) of those measured in field. Confirmation can be provided by experimental tests carried out on these test machines. As regards to the testing protocols, it is recommended to conduct standardized tests in various different planes, by rotating the heel in the fixture on its axis, so as not to neglect the effect of the lateral moment.

\section{CONCLUSION}

This work aimed at investigating by experiments the resistance of high heeled shoes under the most common conditions of use. The heel was substituted by a strain gage instrumented aluminium hollow cylinder with the capability of measuring the axial force by a quarter of bridge connected strain gage, the bending moment in two sections and two directions by eight half bridge connected strain gages and the torque by means of four full bridge connected strain gages. This load cell was calibrated by known loads and a quite diagonal calibration matrix was found.

The complex shape of the stress curves in different key-points of the 11-cm-high heel during an ordinary walk and in particular case-studies (like going up and downstairs, jumping, entry and exit from the car, sitting on the chair, etc.) was evaluated by preliminary experimental measurements on strain gage instrumented shoes. From the analysis of the collected data it was evident that only the flexural stresses are potentially dangerous to the structural strength of the heel. Therefore, it is possible to use a simplified load cell design in monitoring the level of stress in high heels, with only four strain gages, arranged in two orthogonal planes. These load cells permit to acquire the bending moments agents in two directions, while bending moments acting in any other direction can be easily obtained.

\section{REFERENCES}

[1] Bergquist, K., and Abeysekera, J.: Quality function deployment (QFD)—A means for developing usable products, International journal of industrial ergonomics, Vol. 18, No. 4, pp.269-275, 1996.

[2] Schmitt, M., Schick, A., and Becker, J. H.: Subjective quality and subjective wearing comfort of running shoes, Trierer Psychologische Berichte 22, Heft 2. Trier: Universität, Fachbereich I Psychologie, 11 Seiten, 11 Literaturang, 1995.

[3] Archibald, R. B., Haulman, C. A., and Moody, C. E.: Quality, price, advertising, and published quality ratings, Journal of Consumer Research, Vol. 9, No. 4, pp. 347-356, 1983. 
[4] Hui, L.Y., and Hsien, H.W.: Effects of shoe inserts and heel height on foot pressure, impact force, and perceived comfort during walking, Applied Ergonomics, Vol. 36, No.3, pp.355-362, 2005.

[5] Menz, H.B., and Lord, S.R.: Footwear and postural stability in older people, Journal of the American Podiatric Medical Association, Vol. 89, No. 7, pp. 346-357, 1999.

[6] Verdini, F., Marcucci, M., Benedetti, M. G., and Leo, T.: Identification and characterisation of heel strike transient, Gait and Posture, Vol. 24, No. 1, pp. 77-84, 2006.

[7] Verdejo, R., and Mills, N. J.: Heel-shoe interactions and the durability of EVA foam running-shoe midsoles, Journal of Biomechanics Vol. 37, No. 9, pp. 1379-1386, 2004.

[8] International Organization for Standardization: Footwear - Test methods for heels - Resistance to lateral impact, Ref. Num. ISO 19953:2004(E).

[9] International Organization for Standardization: Footwear - Test methods for heels - Fatigue resistance, Ref. Num. ISO 19956:2004(E).

[10] International Organization for Standardization: Footwear - Test methods for whole shoe - Upper sole adhesion, Ref. Num. ISO 177708:2003.

[11] Fragassa, C.: Engineering Design Optimization of Heel Testing Equipment in the Experimental Validation of Safe Walking, International Journal of Quality Research, Vol. 11, No. 2, pp. 242-252, 2017 (in print).

[12]Lee, C.M., Jeong, E. H., and Freivalds. A.: Biomechanical effects of wearing high-heeled shoes, International Journal of Industrial Ergonomics, Vol. 28, pp. 321-326, 2001.

[13] Shiang, T.Y.: The nonlinear finite element analysis and plantar pressure measurement for various shoe soles in heel region, Proc. Natl. Sci. Counc. Repub. China B. Vol. 21, No. 4, pp. 168-74, 1997.

[14] Hana, T. R. et al.: Quantification of the path of center of pressure (COP) using an F-scan in-shoe transducer, Gait and Posture, Vol. 10, pp. 248-254, 1999.

[15] Fragassa, C.: Effect of Natural Fibers and Bio-Resins on Mechanical Properties in Hybrid and Non-Hybrid Composites, AIP Conference Proce-edings, 1736, 020118 (2016); doi: $10.1063 / 1.4949693$.

[16] Fotouhi, M., et al: Effect of PVDF nanofibers on the fracture behaviour of composite laminates for high-speed woodworking machines, Proceedings of the Institution of Mechanical Engineers, Part C: Journal of Mechanical Engineering Science, Vol. 231, No. 1, pp: 31-43, 2017, Doi: 10.1177/ $0954406216650711,2016$.

[17]Zivkovic, I., Pavlovic, A., and Fragassa, C.: Improvements in wood thermoplastic composite materials properties by physical and chemical treatments, International Journal of Quality Research, Vol.10, No.1, pp. 205-218, 2016

[18] Sljivic, M., Pavlovic, A., Stanojevic, M., and Fragassa, C.: Combining additive manufacturing and vacuum casting for an efficient manufacturing of safety glasses, FME Transactions, Vol. 44, No. 4, pp. 393-397, 2016.

[19] Chao, L.P., and Yin, C.Y: The six-component force sensor for measuring the loading of the feet in locomotion, Materials and Design, Vol.20, pp. 237244, 1999.

[20] Gefen,A., Ravid, M.M., Itzchak, Y., and Arcan. M.: Analysis of muscular fatigue and foot stability during high-heeled gait, Gait and Posture Vol. 15, pp. 56-63, 2002.

[21] Putti, A. B., Arnold, G. P., Cochrane, L., and Abboud, R. J.: The Pedar in-shoe system: Repeatability and normal pressure values, Gait and Posture, Vol. 25, No. 3, pp. 401-405, 2007.

[22] McGorry, R.W., DiDomenico, A., and Chang, C.C.: The use of a heel-mounted accelerometer as an adjunct measure of slip distance, Applied Ergonomics, Vol.38, No.3, pp.369-376, 2007.

[23] Jung, K., and Fischer, A.: Methods for checking the validity of technical test procedures for the assessment of slip resistance of footwear, Safety Science, Vol. 16, No. 3-4, pp. 189-206, 1993.

[24]Benno, N.: The Role of Impact Forces and Foot Pronation: A New Paradigm. Clinical Investigations, Clinical Journal of Sport Medicine, Vol. 11, No. 1, pp.2-9, 2001.

[25]Ker, R.F.: The time-dependent mechanical properties of the human heel pad in the context of locomotion, Journal of Experimental Biology, Vol. 199, No. 7, pp. 1501-1508, 1996.

[26] Kinoshita, H., Francis, P.R., Murase, T., Kawai, S., and Ogawa, T.: The mechanical properties of the heel pad in elderly adults, European Journal of Applied Physiology and Occupational Physiology, Vol. 73, No. 5, pp. 404-409, 1996.

[27] Gerritsen, K.G., Van Den Bogert, A.J., and Nigg B.M.: Direct dynamics simulation of the impact phase in heel-toe running, Journal of biomechanics, Vol. 28, No. 6, pp. 661-8, 1995.

\section{ОДРЕЪИВАЊЕ ДИСТРИБУЦИЈЕ НАПОНА ЖЕНСКЕ ЦИПЕЛЕ У ТОКУ ХОДА НА ВИСОКИМ ПОТПЕТИЦАМА}

\section{Ђ. Минак, К. Фрагаса, А. Павловић}

Овај рад усмерен на истраживање оптерећења, напрезања и напона који се јављају приликом хода у пару женских модних ципела са високим потпетицама, са општим циљем да се побољша безбедност обуће. Посебно, отпорност на пети високој 11-центиметара у женским ципелама је процењена путем експеримената под најчешћим условима коришћења (нпр хода, стајања, седења у аутомобилу, устајања са столице, шетањем доле и горе, скакањем). Пета је замењена алуминијумским шупљим цилиндром са мерним тракама које омогућавају мерење деформација у неколико 
критичних тачака. Ове мере су дозволиле да се спроведу комплетне анализе напрезања и деформација у зависности од времена. Деформације су биле повезане са силом у одредјеним тренуцима деловања на ципелама, експериментално извођење ове акције је урађено за сваки услов коришћења. Поређење са стресом насталих током стандардним тестовима је такође извршено. 